\title{
House of risk approach for assessing supply chain risk management strategies: A case study in Crumb Rubber Company Ltd
}

\author{
Taufiq Immawan* and Dea Kusuma Putri \\ Industrial Engineering Department, Faculty of Industrial Technology, Universitas Islam Indonesia, Indonesia
}

\begin{abstract}
Risk is an uncertain and can have both negative and positive impacts. If the risks have a negative impact then a company will incur losses. CRUMB RUBBER COMPANY LTD is one of crumb rubber company in West Kalimantan. The length of the supply chain contained in CRUMB RUBBER COMPANY LTD and the high dependence on suppliers leads to vulnerability. So the purpose of this research is to identify the risk and determine the priority of source of risk along with the priority of handling it on CRUMB RUBBER COMPANY LTD supply chain with House of Risk approach. House of risk approach consists of two phases. Phase 1 is used to determine the dominant risk agent and phase 2 determines the effective action to deal with the dominant risk agent. From the research results, there are 19 risk events and 29 risk agents identified. The result of house of risk in phase 1 is known that 13 of 28 risk agents are dominant risk agent. Then the priority handling strategy in house of risk in phase 2 , in this phase obtained 18 priority risk handling strategies.
\end{abstract}

Keywords: HOR, risk management, SCM

\section{Introduction}

The term SCM was first proposed [2]. Supply chain is a physical network, such as companies involved in supplying raw materials, producing goods, or sending, while SCM is a method, tool, or management approach. Supply chain management is very important to support the smoothness of business activities in the company because supply chain management pay attention to the scope from upstream to downstream.

Risks are uncertain and can have both negative and positive impacts. According [1] the risk is the amount of deviation between expected return and actual return. Meanwhile, supply chain risk is the uncertainty of an event that can lead to disruption of a smooth supply chain in the company.

CRUMB RUBBER COMPANY LTD is a company engaged in manufacturing. This company is one of the manufacturers of crumb rubber which supplies its products to domestic and foreign. The length of the supply chain at CRUMB RUBBER COMPANY LTD and the high dependence on suppliers lead to vulnerability to possible risks. The factors causing the risk of supply chain activity according to [3] include a very complex supply chain network, high dependence on suppliers, the existence of organizational interaction interactions within the supply chain, the short life cycle of a product. Thus, the risk that may occur can adversely affect the company. Therefore, the need for supply chain management to overcome the risks may occur so that companies do not lose and do not hinder the achievement of corporate goals.
Currently PT XYZ does not yet have a structured supply chain risk management in handling the risks. Supply Chain Risk Management or a risk management strategy that can be controlled by a company. The benefits of supply chain risk management are to identify and assess supply chain disruptions and address them.

Based on the background description, it is known that the importance of risk management in the supply chain, so that this study aims to identify the risks and determine the priority of the source of risk along with the priority of the handling of CRUMB RUBBER COMPANY LTD supply chain with the House of Risk approach.

\section{Research Methods}

According to [4] House of risk is a method focused on formulating preventive, reduction and handling of risk factors that potentially lead to more than one risk. House of risk or HOR consists of 2 phases, namely phase 1 and phase 2. In the first phase of House of risk, first mapping supply chain activity and risk identification at CRUMB RUBBER COMPANY LTD by using Supply Chain Operation Reference (SCOR) model. Then performed risk assessment using Failure Mode and Effect Analysis (FMEA) method. This phase is used to determine priority risk agents for precautionary measures. Table 1 is a HOR phase 1 template [4]. 
Table 1. HOR Phase 1

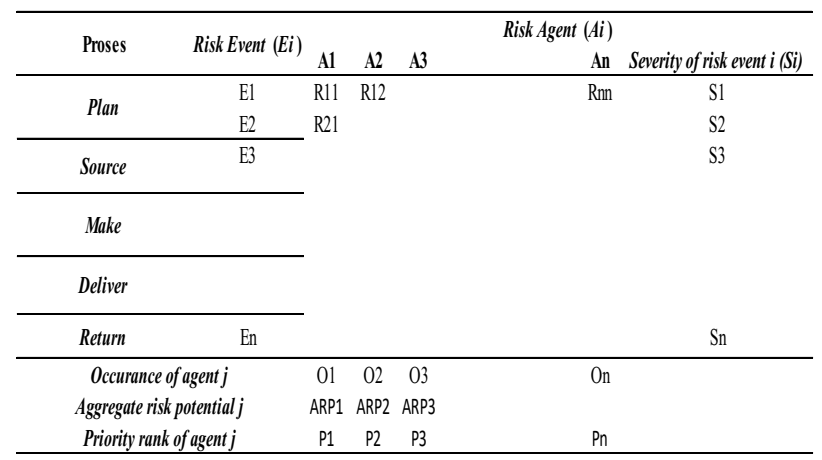

Information:
$\mathrm{A} 1, \mathrm{~A} 2, \mathrm{~A} 3$...An
E1, E2, E3....En
$\mathrm{O} 1, \mathrm{O} 2, \mathrm{O} 3, \ldots \mathrm{On}$
$=$ Risk Agent
$=$ Risk Event
$=$ Occurrence value of the risk agent $(\mathrm{Ai})$
$\mathrm{S} 1, \mathrm{~S} 2, \mathrm{~S} 3 \ldots \mathrm{Sn}$
$=$ Severity value of risk event (Ei)
$\mathrm{ARP} 1, \mathrm{ARP} 2, \ldots \mathrm{ARPn}=$ Aggregate Risk Priority
$\mathrm{P} 1, \mathrm{P} 2, \mathrm{P} 3 \ldots \mathrm{Pn} \quad$ = Ranking of risk agents
based on ARP values

Then perform a 2 nd phase HOR calculation which in this phase determines to the priority of risk management strategies of identification risk agents at high risk level. Where the output of HOR phase 1 will be used as input on this 2 nd phase. Table 2 below is a HOR phase 2 template [4]:

Table 2. HOR Phase 2

\begin{tabular}{cccccc}
\hline To be treated risk agent (Ai) & PA1 & PA2 & $\begin{array}{c}\text { Preventive Action (PAk) } \\
\text { PA3 }\end{array}$ & PAN & $\begin{array}{c}\text { Aggregate risk } \\
\text { priority (ARP) }\end{array}$ \\
\hline A1 & E11 & E12 & E13 & PAn & ARP1 \\
A2 & E21 & & & & ARP2 \\
A3 & & & & & ARP3
\end{tabular}

\begin{tabular}{|c|c|c|c|c|c|}
\hline An & & & & Enn & ARPn \\
\hline $\begin{array}{l}\text { Total Effectiveness of Action } \\
\text { (TEk) }\end{array}$ & TEl & TE2 & TE3 & TEN & \\
\hline $\begin{array}{l}\text { Degree of Difficulty } \\
\text { preforming action (Dk) }\end{array}$ & D1 & D2 & D3 & Dn & \\
\hline $\begin{array}{l}\text { Effectiveness to Difficulty } \\
\text { Ratio (ETD) }\end{array}$ & ETD1 & ETD2 & ETD3 & ETDn & \\
\hline Rank & $\mathrm{Rl}$ & R2 & R3 & $\mathrm{Rn}$ & \\
\hline
\end{tabular}

Information:

- A1, A2, A3...An = Risk agent who was elected to do the handling of

- P1, P2, P3 ...Pn = Preventive action to be performed

- E11, E12,... Enn =Correlation between preventive action and risk agent

- ARP1, ARP2,..ARPn =Aggregate Risk Priority from risk agent

- TE1, TE2, TE3...Ten =Total effectiveness of preventive action

- D1, D2, D3...Dn =Degree of difficulty in the implementation of preventive action

- ETD1, ETD2, ETD3...ETDn =Total effectiveness of divide by degree difficulty
- $\mathrm{R} 1, \mathrm{R} 2, \mathrm{R} 3 \ldots \mathrm{Rn} \quad=$ Rank of preventive action based on sequence of grades ETD highest

\section{Result}

Based on observation and interview with expert, it can be identified the HOR 1 and HOR 2.

\subsection{Risk Identification}

Risk identification is using Failure Mode and Effect Analysis approach. According to [5] that the reason of FMEA usage is FMEA is a technique that can be used to analyze the potential cause of a disturbance, the probability of its emergence and how to prevent it. Giving the value of the variable is done by expert judgment method. Expert judgment is a collection of data provided by an expert on a technical problem [6]. The following is a list of identified risk:

Table 3 Risk Event

\begin{tabular}{|c|c|c|c|}
\hline Process & Activity & Risk Event & Code \\
\hline \multirow{3}{*}{ Plan } & $\begin{array}{l}\text { Production } \\
\text { planning }\end{array}$ & $\begin{array}{l}\text { Forecasting improper } \\
\text { demand }\end{array}$ & E1 \\
\hline & & $\begin{array}{l}\text { Sudden production } \\
\text { changes }\end{array}$ & E2 \\
\hline & $\begin{array}{l}\text { Inspection of } \\
\text { raw material } \\
\text { inventory }\end{array}$ & $\begin{array}{l}\text { The actual amount of } \\
\text { stocks recorded }\end{array}$ & E3 \\
\hline \multirow{5}{*}{ Source } & $\begin{array}{l}\text { Procurement } \\
\text { process }\end{array}$ & $\begin{array}{l}\text { Price negotiations do } \\
\text { not reach agreement }\end{array}$ & E4 \\
\hline & & No offer from supplier & E5 \\
\hline & $\begin{array}{l}\text { Arrival of raw } \\
\text { materials }\end{array}$ & $\begin{array}{l}\text { Delay of raw material } \\
\text { arrival }\end{array}$ & E6 \\
\hline & & $\begin{array}{l}\text { Non-conformity of raw } \\
\text { materials ordered }\end{array}$ & E7 \\
\hline & & $\begin{array}{l}\text { Mismatch amount } \\
\text { ordered }\end{array}$ & E8 \\
\hline \multirow{7}{*}{ Make } & $\begin{array}{l}\text { Production } \\
\text { process }\end{array}$ & Raw material damage & E9 \\
\hline & & Defective product & E10 \\
\hline & & Delayed production & E11 \\
\hline & & Accident workers & $\mathrm{E} 12$ \\
\hline & & Engine failure & E13 \\
\hline & & $\begin{array}{l}\text { Production is not on } \\
\text { target }\end{array}$ & E14 \\
\hline & Quality control & $\begin{array}{l}\text { Not testing product } \\
\text { quality during process }\end{array}$ & E15 \\
\hline \multirow[t]{2}{*}{ Delivery } & $\begin{array}{ll}\text { Delivery } & \text { of } \\
\text { product } & \text { to } \\
\text { buyer } & \\
\end{array}$ & Delivery to buyer late & E16 \\
\hline & & $\begin{array}{l}\text { Product damage } \\
\text { during shipment }\end{array}$ & E17 \\
\hline \multirow[b]{2}{*}{ Return } & $\begin{array}{l}\text { Return of raw } \\
\text { material to } \\
\text { supplier }\end{array}$ & $\begin{array}{l}\text { Delay in complaint to } \\
\text { suppliers }\end{array}$ & E18 \\
\hline & $\begin{array}{l}\text { Handling of } \\
\text { products } \\
\text { returned from } \\
\text { buyers }\end{array}$ & $\begin{array}{l}\text { Delay of product return } \\
\text { from buyer }\end{array}$ & E19 \\
\hline
\end{tabular}


Table 3 Risk Agent

\begin{tabular}{ll}
\hline \multicolumn{1}{c}{ Risk Agent } & Code \\
\hline A mistake in forecasting & A1 \\
\hline Demand a sudden products & A2 \\
\hline $\begin{array}{l}\text { Lacking capacity supply raw materials in a } \\
\text { warehouse }\end{array}$ & A3 \\
\hline Record-keeping error in raw materials in and out & A4 \\
\hline Less coordination between parties internal & A5 \\
\hline $\begin{array}{l}\text { The company did not take into account price } \\
\text { increases that significant }\end{array}$ & A6 \\
\hline Lack of communication with external sides & A7 \\
\hline Accident occurs transportation & A8 \\
\hline Supplier not fulfill a promise & A9 \\
\hline The supplier in producing fluctuant & A10 \\
\hline The storage of the raw material that inadequate & A11 \\
\hline A mistake in selected raw materials & A12 \\
\hline Contaminated with other objects & A13 \\
\hline A mistake in setting an oven manual & A14 \\
\hline The quality of raw materials low & A15 \\
\hline Natural disasters & A16 \\
\hline To limited human resource & A17 \\
\hline Employees arrived late & A18 \\
\hline Occurring bottle neck & A19 \\
\hline The machine breaks & A20 \\
\hline $\begin{array}{l}\text { Employees disobedient in used a protective own } \\
\text { according to standard operating procedures }\end{array}$ & A21 \\
\hline Not held routine maintenance & A22 \\
\hline Limited machine capacity & A23 \\
\hline Schedule a ship erratic & A24 \\
\hline Production late & A25 \\
\hline Interruption along the way & A26 \\
\hline Delays in dealing with the raw material come & A27 \\
\hline $\begin{array}{l}\text { Inspection acceptance of raw materials not } \\
\text { scrupulous }\end{array}$ & A28 \\
\hline
\end{tabular}

\subsection{House of Risk Phase 1}

Assessment of risk event and risk agent is done by field observation, interview to company side by forming team and questionnaire data for severity assessment from risk event and occurrence valuation from risk agent and correlation from both. Based on ARP values that have been obtained from the calculation of HOR phase 1, then further determine the dominant risk agents with pareto approach. According to [7] pareto diagrams are created using the cumulative percentage of each ARP from the risk agent. Figure 1 below shows the pareto risk agent diagram:

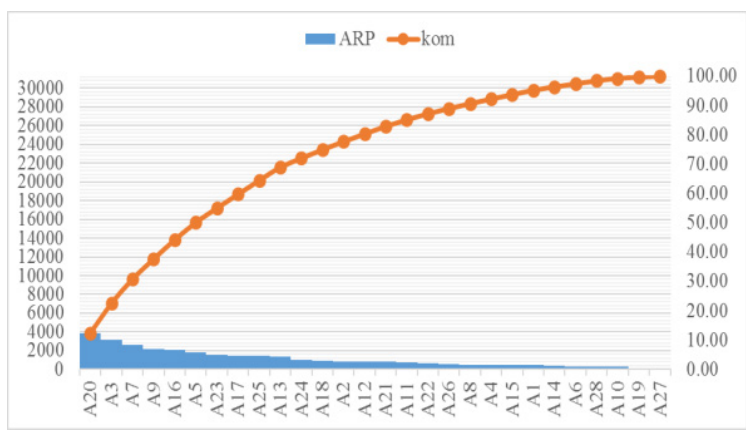

Figure 1 Pareto diagram
From the results of pareto known there are 13 dominant risk agent, including the troubled engine, lack of capacity to supply raw materials in warehouses, lack of communication with external parties, supplier not fulfill the promise, natural disasters, lack of coordination between internal parties, limitations of engine capacity, limitations of human resource, late production, contaminated with other objects, ship's erratic schedule, the employee was late coming, and demand a sudden products After knowing the dominant risk agent then further create a risk map. The risk map is useful to see the risk condition before handling. Here is a risk maps before drafting strategy priority handling:

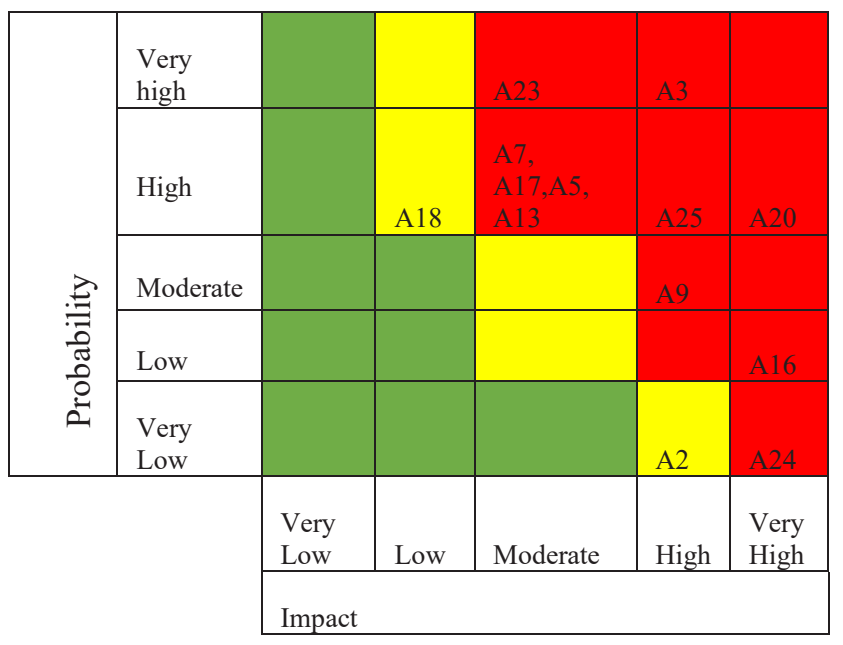

Fig 2. Risk maps before drafting strategy priority handling

\subsection{House of Risk Phase 2}

After completing phase 1 of HOR phase then subsequently entering phase HOR phase 2. From result of focus group discussion resulted 18 strategy preventive action. The following Table 4 of HOR phase 2

Table 4. Result of HOR Phase 2

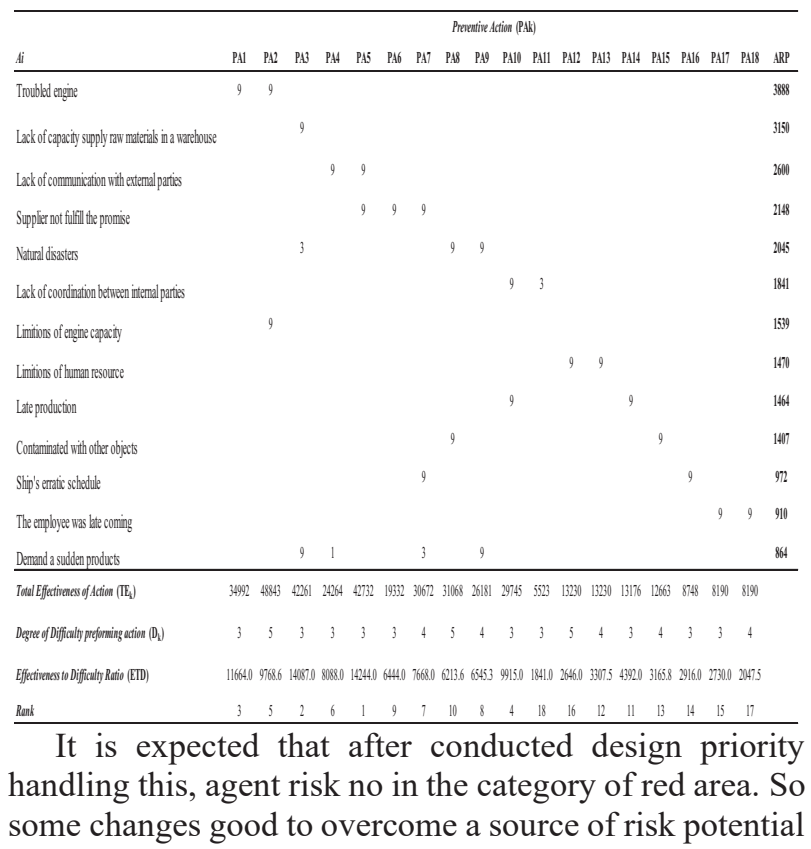


to appear. Figure 3 under showed position risk agent after conducted design priority strategy handling.

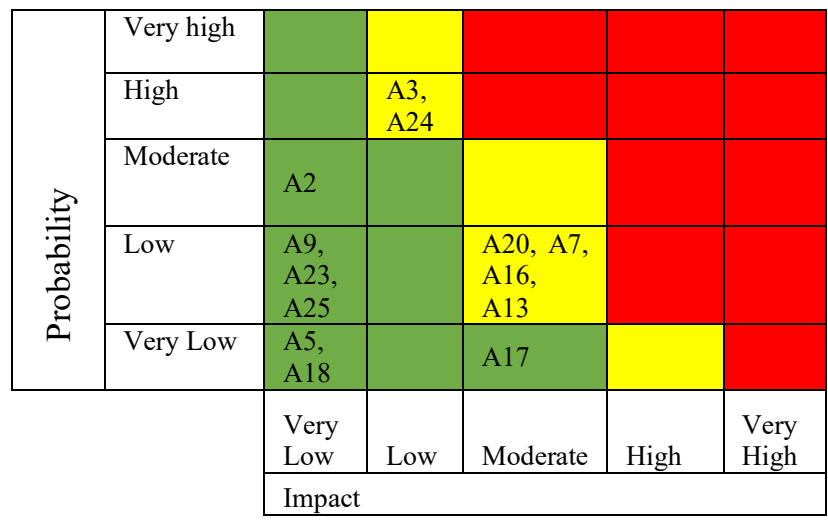

Fig 3. Risk map after conducted design priority strategy handling

\section{Conclusion}

Based on the results of the test which has been done we can conclude that:

1. There are 19 risk event and 29 risk agent identified. From the house of risk phase 1 which has been pareto to come by 13 risk agent that are risk agent priority to handling.

2. After conducting calculation using the house of risk phase 2, obtained priority strategy handling risk of them building relationships closely and communication with supplier, do management safety stock raw materials, discipline implement routine maintenance, improve coordination among parts, buying new machinery, building relationships closely and communication with buyer, make and obey MOU with related parties, planning safety stock finished products, evaluate performance supplier, redesign a work environment where better, rescheduled production, the use of labor off, the use of transportation closed which protected from heat and rain, coordination with the transporters, guidance individual regarding the responsibility of the and discipline time, the addition of labor, the provision of rewards for civil servants discipline and sanctions to did not act discipline, and do briefing routine before activity.

\section{References}

1. Hanafi, M. M. (2012). Manajemen Risiko. Yogyakarta: UPP STIM YKPN.

2. Oliver, R. K., \& Webber, M. D. (1982). Supply chain management: Logistics catches up with strategy. London.

3. Punniyamoorthy, M., Thamaraiselvan, N., \& Manikandan, L. (2013). Assessment of Supply Chain Risk: Scale Development and Validation. Benchmarking: An Internation Journal, 79-105.

4. Pujawan, P. I., \& Geraldin, L. H. (2009). House Of Risk: A Model For Proactive Supply Chain Risk Management. Jurnal Businnes Process Manegement, 963-967.

5. Christopher, M., \& Peck, H. (2004). Building the Resilient supply chain. International Journal Logistics Management.

6. Meyer \& Booker. (1991). Eliciting and Analyzing Expert Judgement: A Practical Guide. London: Academia Press Limited.

7. Caesaron, D., \& Tandianto. (2014). Penerapan Metode Six Sigma Dengan Pendekatan DMAIC Proses Handling Painted Body BMW X3 (Studi Kasus: PT. Tjahja Sakti Motor). PASTI, 248-256. 